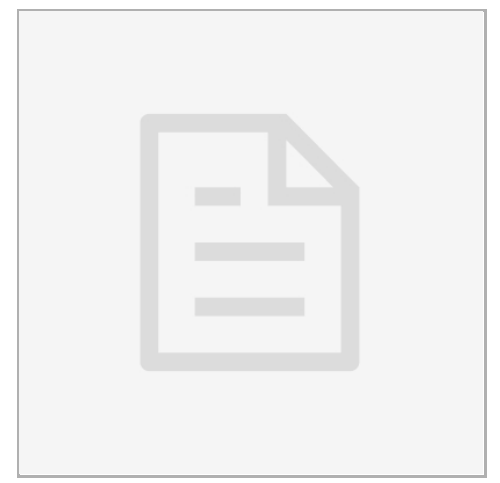

AUG 23, 2020

\title{
(3) Copy of ELISA for quantification of human C5 in serum or plasma.
}

\author{
Angel A Justiz-Vaillant ${ }^{1}$, Belkis Ferrer-Cosme ${ }^{2}$ \\ ${ }^{1}$ University of the West Indies St. Augustine; \\ 2"Saturnino Lora Torres' Provincial Teaching Clinical Surgical Hospital. \\ Cuba
}

Angel A Justiz-Vaillant

University of the West Indies St. Augustine

\section{open ठaccess}

\section{DOI:}

dx.doi.org/10.17504/protocol s.io.bj76krre

Protocol Citation: Angel A Justiz-Vaillant, Belkis FerrerCosme 2020. Copy of ELISA for quantification of human C5 in serum or plasma.. protocols.io

https://dx.doi.org/10.17504/p rotocols.io.bj76krre

License: This is an open access protocol distributed under the terms of the Creative Commons Attribution License, which permits unrestricted use, distribution, and reproduction in any medium, provided the original author and source are credited

Protocol status: In development

We are still developing and optimizing this protocol

Created: Aug 23, 2020

Last Modified: Aug 23, 2020

PROTOCOL integer ID: 40926

1 An anti-human $\mathrm{C} 5$ coating antibody is adsorbed onto the microwells by incubation overnight at $4^{\circ} \mathrm{C}$ with carbonate-bicarbonate buffer. 
2 Add $50 \mu \mathrm{l}$ of human serum or plasma. Human C5 present in the serum or plasma binds to antibodies adsorbed into the microwells.

3 The microplate is blocked with $3 \%$ non-fat milk-PBS buffer and later wash to remove unbound proteins.

4 Fifty (50) $\mu$ l of biotin-conjugated anti-C5 antibody is added. The optimal dilution must be investigated.

5 The microplate is rewashed with PBS-Tween 20 buffer, $\mathrm{pH} 7.4$.

6 One hundred $\mu \mathrm{l}$ of streptavidin-HRP conjugate is added and it binds to the biotin-conjugated antiC5 antibody. The optimal dilution of this conjugate must be investigated.

7 The plate is washed following incubation to remove the unbound Streptavidin-HRP.

8 Add $100 \mu$ l of 3,3',5,5'- tetramethylbenzidine (TMB; Sigma-Aldrich) into each well.

9 Incubate the microwells in the dark for $15 \mathrm{~min}$. 
10 A colored product is formed in proportion to the quantity of $\mathrm{C} 5$ present in the sample or standard.

11 The reaction is terminated by addition of $100 \mu \mathrm{l} 3 \mathrm{M} \mathrm{H} 2 \mathrm{SO} 4$ and the absorbance is measured at $450 \mathrm{~nm}$.

12 A standard curve is made from 7 human $\mathrm{C} 5$ standard dilutions and the human $\mathrm{C} 5$ sample concentration is determined. 